\title{
Staging Romanticism and Dissidence in Howard Brenton's Bloody Poetry
}

Ramin Farhadi ${ }^{1}$ and Mohammad Amin Mozaheb ${ }^{2 *}$

${ }^{1}$ Karaj Azad University, Iran

${ }^{2}$ Imam Sadiq University, Iran

Correspond Author: Mohammad Amin Mozaheb, E-mail: mozaheb.ma@gmail.com

\section{ARTICLE INFO}

Article history

Received: August 07, 2017

Accepted: October 05, 2017

Published: December 30, 2017

Volume: 8 Issue: 6

Advance access: December 2017

Conflicts of interest: None

Funding: None
Key words:
Howard Brenton,
Romanticism,
Power,
Dissidence,
Intellectual,
Thatcherism

\begin{abstract}
Staging history is an approach of historicism that is widely practiced by the post-1968 British playwrights. Historical playwriting not only helps to identify and unmask repressive power institutions, but also to question the conventional trends in writing history in general. One of these playwrights is Howard Brenton. By staging the history of romanticism in the early nineteenth century and the self-imposed exile of Romantic figures in his play Bloody Poetry (1984) Brenton attempts to achieve multiple purposes. By using literary analysis and historical reading, the researchers identify the causes of Shelley-Byron circle's self-exile and the way in which a dissident discourse is formed as an opposition to the mechanism of disciplinary power and one of its powerful discourses which is journalism. In addition to this, they explore Brenton's main politics of representation of the role and function of poet-intellectual in public and how literature as a dissident discourse may function under the administration of Margaret Thatcher in the UK in the 1980s.
\end{abstract}

\section{INTRODUCTION}

Britain in the first half of 1980s witnessed radical changes in economics, society and politics. The ongoing domestic protest against Thatcherite policies, the cuts in welfare payments, Thatcher's confrontation with the National Union of Miners in 1984/5, and the high rate of unemployment were interestingly sufficient for the contemporary British playwrights, such as Howard Brenton, to stand against the rightwing politics of their times. Brenton's theatrical success from Kristie in Love (1969) onward, which established him as a major playwright in large-scale theatre, is associated with such social, political and national issues of his society. What has distinguished Brenton from other contemporaries is that he had a first-hand experience of des èvènements de Mai 1968 in Paris. As Childs (2001) remarks, the basis of all slogans and reforms of the May 68 events derived from the New Left beliefs which included angry young dissidents of Suez campaign and the Hungarian Revolution in the late 1950s (p. 88). As a result, the students' uprising gave rise to leading breakthroughs in the British stage, and one of them was the wide practice of historical playwriting among the playwrights in the 1970s afterward.
According to Zeifman (1993), Brenton's historical approach to stage is to demythologize the prominent events and figures of the past (p. 132). Like other playwrights such as David Hare and Howard Barker, he attempts to reveal the deception of history along with the devastating impacts of historical discourses on characters. This kind of deconstruction enables Brenton to promote his idea of postmodern historicism which, as Eagleton (1996) puts it, is the process of unmasking the power intuitions of the past and their lasting effects upon the present society (p. 34). Brenton's historical approach in his plays involves not only historicism, but also the politics of writing of history. His postmodern historical theory is very close to what Malpas (2005) posited in his book by addressing these questions: "what are the relations and differences between literary and historical forms? Who is able to write history? In whose voice is it written? How can it be rewritten? What are the philosophical and political implications of particular historical forms and structures?" (p. 97).

In this respect, Brenton, for instance, stages two antithetical yet side by side discourses in history plays like The Churchill Play (1974) and Bloody Poetry (1984) - the discourse 
of authority that attempts to write history for its own ideological ends, and the discourse of dissidence that challenges this politics of historical writing by subversive activities. In the former, it is concerning the performance of a controversial play about Winston Churchill, and in the latter play the poetical and intellectual resistance of the major poets of romanticism, Percy and Mary Shelley, Lord Byron and Claire Clairemont, by writing political verse and harassing the character Polidori, a journalist and agent of power. In this regard, Brenton more than any other contemporary dramatist, with the exception of Howard Barker, has engaged himself in what Pattie (2006) has said about the politics of historiography in contemporary British drama that "history is created by contemporary generations" (p. 385). Bloody Poetry not only deals with the question of effective resistance and the role of intellectuals in public, but also it identifies the exercise of power and the forced exile of the free-thinkers resulted in that exercise.

\section{DISCUSSION}

\subsection{Bloody Poetry, Postmodern Historicism and Thatcherism}

Brenton wrote Bloody Poetry in the period when rapid social difficulties of the 1970 s just passed with difficult . The play was first premiered by Foco Novo Theatre Company in October 1984, and up to this point, it is the most performed play of Brenton. Bloody Poetry is a response to problems of the early 1980s as some of the important ones indicated above. Thus, among the goals that the play pursues, the bitter criticism of the Thatcher's overall policy is voiced. Although the setting of Bloody Poetry is the romantic period in the early nineteenth century, Brenton draws parallel the events of Peterloo Massacre in 1819 and Thatcher's confrontation with the miners and Northern Irish dissenters. The historical events and figures of the romantic period enabled Brenton to offer political intervention in his present society. Postmodern theory of history represents history in fragmented forms; there is no meta-narrative or grand narrative, and the history of the dissidents, women and the excluded would be placed in the foreground by such history.

Brenton captures the notion of history as a development and alteration of the world that shapes individual's concept and consciousness in a dramatic writing (Malpas 2005, p. 87). A similar romantic example in fiction is Sir Walter Scott's historical novels. In Waverly (1814) the fictional English protagonist, Edward Waverly, finds himself in the Jacobite rebellion in 1740s within which Scotts make an effort to overthrow the English monarchy since they could re-throne James II; even though imaginary, the novel depicts actual events and social conflicts of Scott's own contemporary culture (ibid p. 88). For political writers, like Scott and Brenton, to use history means to provide raw materials to shape a new narrative that is not based on the existing order or ideologically imposed, but a narrative to be voiced by the dissident and, more importantly, on the alternative point of view that is neglected and hidden.
What is more, Rabey (2003) holds that for post-1968 generation of playwrights, history is a combat zone against exploitative, moral, and ideological discourses (p. 112). The subjectivity, irrationality, open-endedness, and fictionality of history are the key concepts embraced by Brenton in his history plays. Brenton's historical view in Bloody Poetry and in his other dramas can be regarded as the representation of a conflict between history and its antithesis, between rationality and irrationality, and between hegemonic power and dissident discourse. As Garner (1999) puts it, playwrights such as Brenton use "history in order to historicise the present" and to show "that the contemporary moment is the result of past choices" (pp. 9-11). As a case to be illustrated, Polidori in Bloody Poetry is in many ways a contemporary journalist who sides with power and during the play he narrates his own version of history regarding his companionship with the Byron and Shelley. He is an example of journalists whom Brenton criticizes them bitterly in the mid-1980s for their defamatory remarks concerning the men of letters, in particular those who regarded themselves as the dissident voice and critic of Thatcherism.

Margaret Thatcher's attitude toward art and theater was conservative and critical. Thatcherism believed in the idea that arts should be part of creative industry, and the center of this industry would be London. In other words, arts in general need have to satisfy the financial needs of market. In this regard, Day (2001) contends that Thatcher changed the conditions and patterns of the world of art by announcing cutbacks in funds and subsidies in art forms like theater, by centralizing the art in London, and by decreasing university funding programs (p. 170); as an alternative, such arts as melodrama and opera were greatly favored by the Thatcherites. By 1986, more than three hundred British theatrical companies seriously troubled by Thatcherite policies (Pattie 2006, p. 389).

Consequently, Brenton in Bloody Poetry staged the Romantic authors such as Shelley, Byron, Mary Shelley and Claire Clairemont in self-exile in Switzerland and Italy, which power forced them into such exile, to re-evaluate function of poetry (and art) along with the role of the poet as intellectual in the process of political dissent. Hence, in many ways, Shelley is a post-1968 "revolutionary hero" (Brenton, 1995, p. 35). Brenton's other reason of opposition to Thatcherism is that, according to Aragay et al (2007), Thatcher's election victory, and the triumph of the right-wing in general, was a great shock to many post-1968 playwrights like Breton since they fervently believed that a left-wing revolution might take place in the late 1970s (p. 160).

The union between Thatcher and her counterpart in the United States, Ronald Reagan (1981-89), resulted in the promotion of neo-liberalist politics which critically gave rise to the implementation of such policies as privatization, militarism and neo-imperialism. As Fry (2008) puts it, the consequences of Thatcherite neo-liberalism in England were such that the lower and working classes were all doomed to have low conditions of living (p. 30). Many of the British playwrights like Brenton, Caryl Churchill and Edward Bond spent much of their 1980s theatrical 
practice in fighting against the Thatcherite view and policy (Pattie 2006, p. 391).

\subsection{The Role and Function of Poetry and Poet- Intellectual in Bloody Poetry}

Brenton in Bloody Poetry re-evaluates the function of poetry and poet in public, particularly the role of poetry and imaginative writings in general in a contemporary British context that, in his words, is "cranky, tinpot, even silly" (1995, p. 28) because of Thatcherism and Thatcher's attitude toward art that has been mentioned above. It seems that Brenton somewhat feels optimistic about the dissident nature of literature and its uncompromising stance as encountering with power discourses. The play stages the quartet of Percy Shelley, Lord Byron, Mary Shelley and Claire Clairemont in their self-exile in Italy and Switzerland. In the first scene, Brenton's representation of Percy Shelley is significant; his carriage approaches from shadow to light, and the poet's countenance depicted contemplative and gloomy. By this description, Brenton tells the audience how Shelley is a prisoner in this terrifying situation, the self-exile imposed by power. Thus, it is an attempt to be free from any ruling power which according to Mills (2003), it is "liberation from oppression" (p. 35).

The radical generation of the Romantics including Shelley and Bryon were under severe attacks by the periodicals and other forms of press at that time. Most of the time, many of the young Romantic writers had to engage in replying what critics had charged. In this regard, Shelley in his poem Peter Bell the Third () laments that:

"What! - Cried he, "this is my reward

For nights of thought, and days of toil?

Do poets, but to be abhorred

By men of whom they never heard,

Consume their spirits' oil?" (1977, p. 339, 11. 493-97)

Byron too has the same problem. The Edinburgh Review, for instance, in 1807 fiercely criticized Byron's published volume under the title Hours of Idleness. Brenton used these harsh attacks in his play, and also represented the notion of free love and sexual freedom of the quartet as their reasons of self-imposed exile. A case in point is Shelley's self-introduction as "we little band of atheistical perverts, free-lovers, we poeticals - leaving England" (Brenton 1989, p. 239). Journalism represented by Polidori in the text works for power that by putting the subject under surveillance attempt to narrate the parts that might be considered concordant and consistent with its own ideology (). Journalism and the tradition of literary views and critiques written in the press were Brenton's deep concern in the Thatcherite era, and this is evident in the play Pravda (1985) co-authored with David Hare. Bloody Poetry is a drama of parallel between England of 1819 regarding the Peterloo Massacre in Manchester, resulted in the death of nineteen working-class protesters, and Britain of 1980s under the administration of the PM Thatcher.

The political dissidence of Shelley-Byron circle is what highlighted in the play. After 1819, the Peterloo Massacre, Shelley's later works appeared more radically and politically engaged with critical issues such as the exercise of power, protest, and the question of reformation. What repeatedly emphasized in the play is the role and function of writing, in particular the literary composition. When Shelley bewails to Byron that "I write poems. But most of the world cannot even read. So what can I do?” (Brenton 1989, p. 274), it is simply the lamentation of Brenton himself too that he writes plays to raise the audiences' awareness, yet there no change takes place except the victory of the conservatives in the elections of 1979 and 1984.

At face value, although Bloody Poetry might be viewed as the criticism of the above quartet's idealism - as Brenton writes that it "is a celebration of a magnificent failure" $(1995$, p. 35$)$ - the play is a call for revolutionary heroism and effectuality of political resistance against Thatcherism and in general the power of the State. Shelley makes clear the point and mentions the terrible consequences of State's hegemonic power:

England. England. A people starved and stabbed in the untilled field. Rulers who neither see, nor feel, nor know. But leech-like to their fainting country cling, till they drop, blind in blood.

Men of England, wherefore plough

For the lords who lay yet low? (Brenton 1989, p. 239)

Here, the discourse of power in England in the early nineteenth century is the one that causes grave social crises. In above Shelley' words, socio-economic problems are ignored by the rulers; people encounter unemployment: "A people starved and stabbed in the untilled field." moreover, Shelley invites the people, in his poem "England in 1819" to rise against those authorities whose "army, which liberticide and prey" (1977, p. 311, 1. 8).

When it turns to the function of literature in society, it is important to note that as Williams (1960) contends that for Romantic poets any conclusion concerning personal feeling is a conclusion regarding society as a whole (p. 33); in consequence, a Romantic poet instead of devoting himself completely to celebrate natural beauty and inspiration, he deeply concerns social affairs and national politics (p. 33). The same thing is identified with Shelley and Byron in the play. Makdisi (2009) too writes that Shelley believed in the power of ancient Hellenic civilization as an initial pattern (p. 618). As Stock (2010) states, Shelley scrutinized the entire English society and the place of poetry in his A Defence of Poetry (1821) so as to arrive at this conclusion that poetry (and literature) might be regarded as the most powerful instrument of change and reformation in a society (p. 128). It can have the potential for building communities.

The historical Shelley (1977) placed a great emphasis on the role of poetry as the "eternal truth" in life (p. 485) and the poets as those who speak truth and are "the world legislators or prophets" (p. 482). This definition is in affinity with Edward Said's definition of an intellectual (1996) as someone in "exile and marginal" who "tries to speak the truth to power" (p. xvi). In Said's view, in pre-modern eras exile was used for punishment or cutting off an individual entirely, while in the present society it is a condition associated closely with an intellectual (pp. 47-9). Shelley in Brenton's play 
is a lonely figure; the play begins by him lonely in a carriage and in many scenes of the play he is alone and reciting his political poems. His sadness in the play is not that he is in self-exile but emanates from the fact that his writing is neglected in English society.

Power functions as a major barrier against the publication of his poetic compositions and the reception of them. It is this case that Mary Shelley expresses her opinion about Shelley's 'The Mask of Anarchy' as a “great revolutionary, English poem - unpublishable!"” (Brenton 1989, p. 302). Moreover, in a monologue, Polidori asks that "has Shelley ever had a good review in life?" (ibid, 261) which he, then, negatively describes Byron and Shelley as "an overweight alcoholic" and "an anorexic, neurotic mess" respectively (ibid). It appears quite evident that power pursues the goal of suppressing the dissident voice and driving the intellectuals out of England to its own ends. Shelley believed in the centrality of education as a fundamental factor for shaping and maintaining a dynamic idealized life; in this respect, men and women have the same share in creating community (p. 363). Education, for Shelley, will be promoted and extended by using poetry and literary writings, and this can be seen throughout Defence of Poetry, repressive power institutions such as the press whose representative in the text is Polidori function as a formidable barrier to such Shelleyan vision.

\subsection{Power and Dissident Discourse}

Throughout the settlement of the quartet from 1816 to 1822 in the play, disciplinary power exercises itself side by side with them. Mills argues that disciplinary power is "a form of self-regulation" that is born out of bourgeois power as a subtle tactic for domination (2003, p. 42). This shift in power after the French Revolution is coupled by the emergence of Romanticism with its established critical principles in Western Europe. When Wordsworth (1991) in his famous preface to Lyrical Ballads (1800) announced his confirm tion that "the present state of the public taste" (p. 328) is the "language of conversation in the middle and lower classes of society" (p. 317), he aesthetically and politically was establishing and calling forth the democratic power of bourgeois class against flower, ornamental diction of aristocracy. This is the point that Byron in the play severely reprimands Wordsworth for his conservative position and his lack of political commitment especially in the Reign of Terror and the establishment of a revolutionary State: "Not another damn Wordsworth. I do distrust a sober poet who writes of nothing but ecstasy. Like a virgin writing hymns about the delights of a brothel" (Brenton 1989, p. 245).

Alongside of the discussions about poetry and the role of a poet in public, another important factor which is influential in Shelley-Byron circle's self-exile is the matter of sexuality. While in England, as Foucault (1977) puts it, they have to discipline the self (p. 44) in a country that is considered as conservative. Shelley was married to Harriet Westbrook, yet he abandoned her and eloped with Mary Godwin. Byron's sexuality was even more notorious than Shelley's. He had numerous unauthorized sexual relationships with many women including an allegedly incestuous relationship with his half-sister Augusta Leigh. According to Schor (2009), Byron's strong sexual desires together with the iconoclastic nature of his poetry were the factors in Byron's chastisement in the English press, and thus resulted in his self-imposed exile (p. 229). There are some references to these issues in Brenton's play like Claire's statement to Mary about her reading of Byron's secret love letter to Augusta: "dear Augusta, we have a true marriage, sealed in heaven witnessed in hell, forever" (Brenton 1989, p. 271).

The Shelley-Byron circle's sexuality, in the eye of power and society, were regarded as abnormality and culturally rejected. In this respect, Mills states that eradication of incest and sexual sex life is a top priority for disciplinary power to control and keep a society (2003, pp. 83-4). She then adds that the main concern of bio-power (power over life) is to regulate and restrain population and sexuality (ibid, p. 84). The reason of this strict control over sexuality was that it is highly associated with individual and political dissidence, or to put it in terms of Renaissance England, as Dollimore (2004) puts it, it is a matter of subversion (p. lxix). To stage sexuality as a form of dissidence is a legacy that Elizabethan and Jacobean dramatic literature continues to influence later imaginative writing and post-1968 British political playwriting as well.

Smart (2002) argues that when sex is confined to a relation in a bedroom, this will be a matter between the State (that forbids sexual frankness and sex in public) and an individual (p. 92). Accordingly, in this society, it is the perfection of control and regulation; in this sense, power institutions established throughout the $19^{\text {th }}$ century English society were aimed at studying and dominating people's sexuality to dominate the bodies and maintain social order (p. 92). Sexuality of the quartet in Bloody Poetry is a means of violation of power mechanism. It is mode of resistance that for several times horrified Polidori addresses it. As Brenton himself writes in the preface, the self-exile of them is to be "free of sexual repression" (1989, p. xiv).

Hunt (1993) contends that the use of sexuality and erotic images were instruments of criticizing the authorities of religion and politics (p. 10). Brenton extends the scope of Hunt's argument and related to his play under discussion; thus, Shelley and Mary are violating the institution of marriage and power authorities in the UK by their notion of free-love and sexual freedom, not to mention Lord Byron's overt sexuality. Their notion of free love violates the order of sociopolitical power. For this reason, power has to exercise itself even in countries outside of England to put Shelley-Byron circle under observation. And the best discourse in this respect might be newspaper journalism with its ideological stances and specific lines of thoughts; as a result, Polidori accompanies the quartet in order to have an eye on them and report their every moment. For example, when he enters the house and faces the quartet he describes them as "the profligate would-be poets and their, their whores, lounged upon the floo, and felt disgraced at my entrance, for I brought with me the wind and the rain" (Brenton 1989, p. 242). Moreover, Claire too expresses her resentment that Daily Mail has called Mary and her, "Shelley's ball girls" (ibid, p. 244). 
Despite being introduced by Byron as his physician, Polidori is Byron's biographer too. His role in the play is significant; he is the eye of power. As Boon (1991) explains, Polidori's companionship to the quartet is to fulfill the goal of questioning the group's utopian thinking and radicalism (p. 261). The representation of Polidori and his presence in the play help Brenton to conduct trial the quartet's means and methods of dissidence. In this regard, Brenton gives voice to a man who is the laughing matter of the quartet, particularly Byron and Mary Shelley of whom the latter represented Polidori in the novel Frankenstein and gave him a sinister role as Victor Frankenstein's evil teacher (Brenton 1989, p. 237).

Journalism as a part of media is one of the ideological state apparatuses (ISA) defined by the French thinker Althusser. As Hawkes (2003) the main function of ISA is to support ideological positions of the State and to perform the exercise of power regularly (p. 118). The historicist approach which Brenton employs to stage Britain and its affairs in his play is postmodern in a sense that the continuation of power institutions from past to present can easily be seen. All the references in the play about the way English press are dealing with Shelley-Byron circle, like this statement that "In England they want to hang us all" (Brenton, 1989, p. 243) might be presentist. Hirst (1985) maintains that in 1980 due to the staging of The Romans in Britain in which a "political message" conveyed by the representation of a male rape (p. 106), the British media violently attacked Brenton and the director of the play which resulted in imposing a ban on the performance of the play. The press that Brenton attacks in the text is an instance of gutter journalism:

Claire: Remember what the Daily Mail called us?

Mary: All too well.

Claire: 'Shelley's ball girls...

Mary: Gutter journalism

Claire: The real world. (ibid, p. 244)

However, the reaction of the quartet to the press, which in the play represented by Polidori, is telling. He is for several times ridiculed by them. Byron mocks his name; Mary Shelley based a sinister character in her fiction on him, and generally they pay no attention to him, as Polidori himself mentions this one of his asides (ibid, p. 242). Accordingly, the climax of ridiculing Polidori is the moment that the quartet enacts Plato's Idol of Cave. They seize Polidori and put him in chains. Byron assures him that his chaining is "the human condition, doctor!" (ibid, p. 264); thus, it is a reference to modern power and its disciplinary means, including surveillance and gutter journalism. In brief, by enactment of Plato's Idol of the Cave and enchaining Polidori, they symbolically can overpower the English press. During the enactment, Mary Shelley repeats the word "prisoners" for several times (ibid, p. 265), and her exasperated tone suggests that modern societies are the ones under influence and observation of gutter journalism and the ideological media.

However, after acting out the Idol of the Cave, Polidori becomes more sarcastic than ever. Arendt (1970) contends that in connection with violation of power relation, power would exercise its sovereignty more fully and effectively (p. 46). Therefore, he begins to express openly the hidden causes of his presence with the quartet by using animal-related vocabulary:

The Shelley menagerie, women, children, bays of seditious material, fleeting the country... These people! Am I condemned to be the nobody at their feast? I will not make myself known. I will dog them. (Brenton 1989, p. 286)

Given this fact, this is precisely the way in which disciplinary power exercises itself everywhere: surveillance is also a means of imprisonment, though not physically but mentally even in a foreign soil. Polidori may fulfill his objective by sending "back tasty bits to the literary magazines" (ibid); the "bits" that are teemed appropriate to power. On this account, from Polidori's perspective, the quartet is a menagerie that should be stopped without delay: "They must not win. I could not stand it" (ibid, p. 290). For power, they must be defeated since violation in power mechanism is not acceptable. In the same way, Foucault too argues that power can be successful when it has dominating observation over its subjects (p. 171).

In the second act two incidents influenced characters and the course of the play. Somehow in this act Brenton attempts to question the attitude and the irresponsibility of the dissident intellectual. The first is the news of Shelley's ex-wife's suicide, Harriet Westbrook. By this, Brenton puts an intellectual's life and the sense of Shelley's responsibility into question. The ghost of Harriet from time to time haunts Shelley in the second act. Regarding the case, staging ghosts in the postwar British theatre is largely associated with the guilt and conscience of a character. Although Brenton stages Shelley as a revolutionary hero in his contemporary society, the representation of Shelley's abandoned wife's ghost refers to both the chaotic situation that Shelley is facing with and the adverse effect of the past on his present condition (Boon 1991 p. 263). This is a criticism that Brenton centers on the play's second half that imagination is not only rest on poetry but also on the realities of life (ibid, p.264). Throughout the text, Shelley's mind either preoccupies citing his poems, sinking into his own world of imagination, or thinking about the unpleasant, chaotic situations like seeing of Harriet's ghost and the turbulence that emerges afterward.

The second incident is the news of Peterloo Massacre which exactly coincides with the news of the death of the Shelley's infant son. Brenton's reference to Peterloo Massacre in Bloody Poetry which was the result of the State's brutal repression of the members of the working class in Manchester in 1819 serves as indication of Thatcher's bitter confrontation with the minorities, working class, and the intellectuals that Collini (2006) has mentioned in his study of British intellectuals (p. 193). As a result, Castlereagh the dictator administrator in the early nineteenth century, for Brenton, is the modern version of PM Thatcher. Eagleton (1996) also points out the central cause of these two historical suppressions was the birth of authoritarian disciplinary power after 1789 and 1968 in the Western Europe (p. 19). Brenton's holds the news of Castlereagh to the end of the play in order that the real father-figure of both Shelley and Byron reveals to the audience that lack of responsibility of the two poets finally led to the death of Shelley's son and Byron's daughter (Brenton 1989, p. 226). Yet Shelley's telegraphic style 
of conveying the news of massacre to Mary is significant because it is Brenton's own concern about the function of intellectuals and the politics of mass media in covering the gutter and trivial news of celebrities instead of delivering major and serious news:

I can see it! St. Peter's Field - the outskirts of Manchester. A great crowd, some 60,000 working men and women. Armed only with banners.

And then, from nowhere - the militia. The brutal attack. In ten minutes, a massacre. Eleven dead, four hundred and twenty-one cases of serious injury, one hundred and sixty-two, men and women and children with sabre wounds.

And where was I? [...]

The world is catching fire, the oppressors have bloodied their hands! But what excites the educated classes? The behaviour of the rich and famous in bed. (ibid, p. 300)

Harrison (1994) explains that the main cause of ineffectuality of British intellectuals, particularly at the time of Thatcher, was concerning the lack of lifestyle (p. 206). He then adds that they lack "a taste of creating, discussing, criticizing, and recycling ideas and ideals" (ibid). Shelley and Byron are both irresponsible and cruel to their children and the women accompanying them. Although in some cases they see eye to eye, they are apart from each other, and this is the criticism of Brenton. However, broadly speaking, Brenton's staging the Romanic history of Britain and the Peterloo Massacre along with three of its literary figures, Percy and Mary Shelley and Byron, enabled him to wage war against the British authorities like PM Thatcher.

To conclude, poetry is bloody since Byron's attitude toward the function of poetry is both dark and politically effective; he places emphasis upon the subversive characteristic of poetry since in the course of history many poets and literary figures were imprisoned, tortured, excluded, and, even in some extreme cases, executed by the religious and political authorities: “...you think poetry harmless sir? Sir it can maim, it can mutilate, it can imprison men, women and children, blinded for centuries, it can kill, sir, I thought you an intellectual - do you know how ideas can kill?" (Brenton 1989 , p. 265); this is why he, after Shelley's death in 1822 , fought against the Ottomans for the independence of Greece. At the end of the play, he laments the lack of consistency and unanimity among the British intellectuals and the silence of the people:

A war. And if there were a war in England, not that endless-slow, sullen defeat. Why don't the bastards take up arms against such a government? Then we poets would be of some use, we'd do the songs, the banners, the shouts, but no. sullen silence. (ibid, 304)

The play ends with the drowning of Shelley in 1822 . Polidori's final victory is his prediction of Shelley's death and the degeneracy of the quartet's utopian life. Polidori speaks to the audience that "I saw Bysshe Shelley jump into his boat, in Livorno Harbour, with the storm coming, my opinion? Suicide, yes, no doubt..." (ibid, p. 307). Polidori's statement here resembles the Lodovico in Shakespeare's Othello that the story of Othello, Desdemona and Iago, as Sinfield (1992) maintains, might be told according to the interests of the authorities (p. 34). It can be said that
Shelley's death is, to a certain degree, the death of a revolutionary hero-intellectual in the UK after the events of May 1968.

\section{CONCLUSION}

By staging the Romantic poets like Shelley and Byron Brenton in Bloody Poetry makes a comparison between the early nineteenth century and his contemporary British society. In the play, Brenton dramatizes two antithetical discourses at the same time: discourse of dissident and of power. Brenton's representation of Shelley and Byron is two intellectuals away from their homeland and even in their self-exile the representative of English journalism, linked to ideology and power, is Polidori, and he forms the discourse of power in the text. Although, Brenton at the end of the play somehow questions the lifestyle and attitude of Shelley and Byron toward their children and the women accompanying them, he reveals that the cause of their self-exile and resentment about the British society is the exercise of power and the exclusion of poets as intellectuals.

Another goal Brenton pursues in his play is to challenge the Thatcherites and the politics of Thatcherism. Thatcher's policy toward art, society and welfare is the main reason of the playwright's objection in the play. Regarding the issue, Brenton uses the historical Peterloo Massacre and the negative reviews and various attacks on Shelley and Byron to forge a link to his present society under the government of Thatcher. Briefly speaking, for him, this historical material is the appropriate subject to form an attack on the ideological institutions of power in modern Britain, for example, journalism and the politics of the press.

\section{REFERENCES}

Aragay, M., Klein, H., Monforte, E. \& Zozaya, p. (Eds.). (2007). British Theatre of the 1990s: Interviews with Directors, Playwrights, Critics and Academics. Hampshire: Palgrave Macmillan.

Arendt, H. (1970). On Violence. San Diego: A Harvest Book. Boon, R. (1991). Brenton: The Playwright. London: Methuen.

Brenton, H. (1989). Plays: Two. London: Methuen.

Brenton, H. (1995). Hot Irons: Diaries, Essays, Journalism. London: Nick Hern Books.

Childs, D. (2001). Britain since 1945: A Political History. London: Francis \& Taylor.

Collini, S. (2006). Absent Minds: Intellectuals in Britain. Oxford: Oxford University Press.

Dollimore, J. (2004). Radical Tragedy. London: Macmillan. Eagleton, T. (1996). Literary Theory: An Introduction ( $2^{\text {nd }}$ ed). Oxford: Blackwell.

Foucault, M. (1977). Discipline and Punish: The Birth of the Prison (A. Sheridan, Trans). London: Allen Lane.

Fry, G. (2008). The Politics of the Thatcher Revolution: An Interpretation of British Politics, 1979-1990. Hampshire: Palgrave.

Garner, S. (1999). Trevor Griffiths: Politics, Drama, History. Michigan: University of Michigan Press. 
Harrison, B. (1994). Mrs Thatcher and the Intellectuals. Twentieth Century British History. Vol 5(2): pp. 206-45. Hawkes, D. (2003). Ideology ( $2^{\text {nd }}$ ed). London: Routledge.

Hirst, D. (1985). Edward Bond. London: Macmillan.

Hunt, L. (1993). Introduction: Obscenity and the Origins of Modernity, 1500-1800. In L. Hunt (Ed.), The Invention of Pornography: Obscenity and the Origins of Modernity, 1500-1800 (pp. 9-45). New York, NY: Zone Books.

Makdisi, S. (2009). Romantic Cultural Imperialism. In J. Chandler (Ed.), The Cambridge History of English Romantic Literature (pp. 601-20). Cambridge: Cambridge University Press.

Malpas, S. (2005). The Postmodern. London and New York: Routledge.

Mills, S. (2003). Michel Foucault. London: Francis \& Taylor.

Pattie, D. (2006). Theatre since 1968. In M. Luckhurst (Ed.), A Companion to Modern British and Irish Drama (pp. 385-97). Malden: Blackwell Publishers.

Rabey, D. I. (2003). English Drama since 1940. London: Longman.

Said, E. (1996). Representations of the Intellectual: The 1993 Reith Lectures. New York, NY: Vintage Books.
Schor, E. (2009). The Warm South. In J Chandler (Ed.), The Cambridge History of English Romantic Literature (pp. 224-45). Cambridge: Cambridge University Press.

Shelley, P. B. (1977). Shelley's Poetry and Prose. D. Reiman \& S. Powers (Eds.). new York, NY: W.W Norton \& Company.

Sinfield, A. (1992). Faultlines: Cultural Materialism and the Politics of Dissident Reading. Berkeley: California University Press.

Smart, B. (2002). Michel Foucault ( $2^{\text {nd }}$ ed). London: Routledge.

Stock, P. (2010). The Shelley-Byron Circle and the Idea of Europe. London: Macmillan.

Williams, R. (1960). Culture and Society 1780-1950. New York: Anchor Books.

Wordsworth, W, \& Coleridge, S. T. (1968). Lyrical Ballads. R. L. Brett \& A. R. Jones (Eds.). London: Methuen.

Zeifman, H. (1993). Making History: the Plays of Howard Brenton. In J. Acheson (Ed.), British and Irish Drama since 1960 (pp. 130-45). London: Macmillan. 